JES

34,6

454

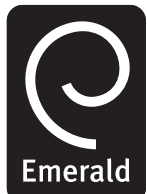

Journal of Economic Studies Vol. 34 No. 6, 2007

pp. $454-475$

(C) Emerald Group Publishing Limited 0144-3585

DOI $10.1108 / 01443580710830943$

\section{Dynamics of fiscal and current account deficits in Thailand: an empirical investigation}

\author{
Ahmad Zubaidi Baharumshah \\ Department of Economics, Faculty of Economics and Management, \\ Universiti Putra Malaysia (UPM), Selangor Darul Ehsan, Malaysia, and \\ Evan Lau \\ Faculty of Economics and Business, Universiti Malaysia Sarawak (UNIMAS), \\ Sarawak, Malaysia
}

\begin{abstract}
Purpose - The purpose of this paper is to contribute further on the twin deficits debate in a developing economy.

Design/methodology/approach - The data for Thailand over three decades are used as a case study.

Findings - The major findings are: first, a stable, long-run equilibrium relationship between fiscal deficit, interest rate, exchange rate, and current account was found. Second, the causal relationship between the two deficits runs from fiscal deficit to current account deficit. This evidence is supportive of the twin deficits hypothesis. Further econometric analysis reveals that the two financial variables (interest rate and exchange rate) act as intermediating variables - that is an increased fiscal deficit causes interest rate to rise, and this in turn puts pressure on the exchange rate. The appreciation of the domestic currency causes a current account deficit.

Originality/value - The paper is of value by showing both direct and indirect channels to uncover the twin deficits phenomena. Based on a persistent profile response, it was found that the adjustment process may take as long as a year to complete.
\end{abstract}

Keywords Fiscal measures, Exchange rates, Interest rates, Thailand

Paper type Case study

\section{Introduction}

Thailand's economy emerged as one of the fastest growing economies in the Asia-Pacific region in 1990 and it has been hailed as the "Fifth Tiger" (Warr, 1999). The spectacular growth performance of the economy prior to the 1997 financial crisis has been mainly attributed to the regime switch from import substitution industrialization and to export-oriented industrialization strategy in the late 1970s[1]. Thailand was the hardest-hit economy during the East Asian financial crisis. To cope with the crisis, it was forced to embark on the IMF-mandated program by committing to float the exchange rate and tighten both monetary and fiscal policies. It has been more than nine years since the onset of the East Asian financial crisis and Thailand has returned to a position of

This paper has benefited from the valuable comments of the anonymous referee and the Editor of this journal. This research was partly funded by UNIMAS Fundamental Research (Grant No. 03(72)/546/05(45), which is gratefully acknowledged. All remaining errors are the responsibility of the authors. 